\title{
The Influence Study of Western Opera to Chinese Opera Creation
}

\author{
Haijing Shi \\ Xi'an University, Xi'an, shaanxi province, China
}

Keywords: Western opera, Chinese opera, Opera creation, Impact study.

\begin{abstract}
Due to differences in environment, culture and other factors, led to the region, the different art forms, between national and ethnic Chinese opera and western opera is the most typical representative. Between Chinese opera and European opera stage art there are many similarities in both, and there is the difference between "qualities". The former represents is an important form of Chinese opera, the latter is represented by the western drama performance of important form. From the point of art generated, it is classical philosophy by relying on each other and deep cultural background differences thus formed their own unique artistic style and performance system. This article tries from their respective forms and cultural backgrounds, through both trajectory, explore the similarities and differences of both, analyzed the influence of western opera to Chinese opera creation.
\end{abstract}

\section{Introduction}

Whether it is the east, the west, the world's peoples have their own unique culture, the culture of all nationalities in the world are exist in our nation's deep roots, was born with national burden. In all art, is the most direct and the most comprehensive to reflect the cultural spirit is the drama of life. Drama stage, is actually a microcosm of culture, can see from the drama stage social development rule of "root". Chinese opera and European opera art relies on local profound background of classical philosophy and culture, formed a very unique style features and complete system, with its self-contained personality color in a tripartite balance in the world of Chinese opera [1]. Between Chinese opera and European opera stage art there are many similarities in both, and there is the difference between "qualities". The former represents is an important form of Chinese opera, which represents is an important form of western drama, because of different cultural background, there are big differences between the two art forms is a cultural history.

Chinese opera has nearly hundred years of history, after several generations of hard exploration, has become an important part of modern Chinese literature and art. After the founding of new China, Chinese songs play in the new historical conditions for faster development. In the early $1950 \mathrm{~s}$, many composers, playwrights and opera performing artists to explore "new opera" with great enthusiasm. Therefore, the new China opera stage reflect a large number of excellent dramas, present a different type, style, style [1]. Among them, there are following the founding of the former liberated areas little song style of opera, with reference to the European "is an opera" style of opera, and draw lessons from Chinese opera, court. But exactly what kind of the mouth of the opera is more suitable for the Chinese audience confused and can become the development direction of Chinese opera? It certainly requires opera nationalization exploration.

\section{The similar place between Chinese opera and western opera}

When we watch a musical, we would be on stage are created by the atmosphere of artistic conception and a variety of different characteristics of music and dance, will also be infected by the gorgeous vivid scenery, imperceptible will immersive [1]. And when we taste a Chinese drama, we will be the business-like singing, there is a recruit a type of figure, and simple but occasional stage arrangement and don't detail processing of Oriental verve and admit defeat. 
One is gestated in the west of elegant open born; one is in the east of the classical restraint. Western operas are cultivated in the west the vast land of flowers of art, has the striking characteristics of its own, and the essence of Chinese traditional opera is very different [2]. Shakespeare's famous playwright in their own work, and enrich Ibsen, extensive and profound reflect their era. But they do not belong to an era and a nation, but belongs to all of the century and the world.

Regardless of time or space, western operas and Chinese operas have many similarities and differences:

\subsection{From the historical view, Chinese opera and western opera has a long history.}

Imitation of Chinese opera has a long history, from the earliest primitive society of labor is formed in the song and dance, and western operas have also can be traced back to ancient Greece tragedy. Chinese opera after infancy of pre-qin period to the early tang long eventually formed in the tang dynasty, and then to the period of song, Jing to mature, finally ushered in the unprecedented boom during the Ming and Qing dynasties. Western opera is through the medieval and Renaissance evolution of the development of numerous music forms finally was born in the 16th century [2]. Visible Chinese opera and western opera also has experienced a long development and change, finally formed today's face.

\subsection{Chinese opera and western operas are comprehensive stage art form.}

Opera is a comprehensive art, comprehensive, is the time space of art and the art of the integrated is shared by the world drama culture, and Chinese opera are particularly strong. Chinese opera singing, reading, doing, playing integrated center for the performing as forms of drama, it has a lot of means of artistic expression, and acting together, it is the song words, music, art, show the beauty of electro slag casting as a whole, with rhythm controlling in a play, achieve the harmonious unification, makes Chinese opera rich special charm and appeal [2]. Western opera music, literature, dances and drama into an organic whole, with singing role is given priority to, in a particular story development music structure. As a result, Chinese opera and western opera are fused cast their culture art thousands of years of accumulation, make all kinds of art forms under the heads of the drama of racing to release its beauty.

\subsection{Chinese opera and western operas have formed many types and genres.}

According to incomplete statistics, China's ethnic minority areas is about more than three hundred and sixty kinds of different types, various performances, and has its own performance style and genre. Western operas have different levels of development in all countries, and produce the playwright, distinctive and different folk customs of distinctive drama works [2]. Can say, two kinds of art forms to present diverse forms reflect both the diversity of culture.

Two kinds of art forms on the history and form although has many similarities, but is more reflected in the different aspect of the development of Chinese and western music also reflects the different ethnic customs and aesthetic point of view. The following is from the Chinese traditional opera and western opera compares internal external differences.

\section{The difference between Chinese traditional opera and western opera}

\subsection{External differences between Chinese traditional opera and western opera.}

Chinese traditional opera and western opera plays are literary language, this is their general character. But both languages and each has its own characteristics. Drama script is verse and prose combination of literature, poems rhyme; spoken parts usually prose, sometimes in rhyme. ChangCi and spoken parts should have musical drama. Opera literature scripts for vernacular prose commonly, the lyrics are required actions [3].

\subsection{The inner differences between Chinese traditional opera and western opera.}

Chinese opera is the most important features in virtual sex. Stage art is not simply imitating life, but to choose life prototype, refining, exaggeration and beautification, the audience directly into the 
palace of art [3]. And western opera is mainly realistic, roughly it's stage time is equal to the time of life, the actor will become what he play the role of, is to be in character. Western opera want to erase any traces of "play" on the stage.

\subsection{Historical and cultural background differences.}

Opera and the time background of Chinese opera art form. Opera drama is the 16th century, at the beginning of the 17th century, as the European Renaissance music culture secularization arises at the historic moment, is the result of the development of music art during the Renaissance, that originated in Italy in the original, it is closely related to the special cultural background; Chinese opera forms in before and after the twelfth century, during the song and Yuan dynasties, 400 years earlier than the emergence of the opera [3].

And Chinese opera art has the same basic aspects of form, but there are also different. They are nurtured in the folk song and dance performances and singing and dancing with the plot, this is both the foundation of the formation of art of the same. In opera inoculation, the city of classical distresses, comedy shows, the penetration and the emergence of "interact", late Renaissance and people's interest in music from the polyphonic music form to advocate tone music form, has a significant effect on the birth of opera.

\subsection{The different time background between Chinese opera and western opera.}

Art rooted in people's life, and music and art are derived from folk music, each has each ethnic characteristics. There are three kinds of ancient drama culture in the world: one is the Greek tragedy and comedy, 2 it is India Brahman drama, three is a Chinese opera. Visible Chinese opera in the world art treasure house has special important position [4]. The origin of the early Chinese opera, and already germination in the ancient songs and dances are in the primitive society, the development of the Han and tang dynasties to the song growth process to form a more complete opera art form. Chinese classical opera is an important part of the Chinese nation culture, she in the form of a full of artistic charm of performance for all previous dynasties are very popular among the people. Form of opera, as can be traced era of Qin and Han dynasties. But forming process is quite long, the song and Yuan during molding. Mature dramas from the Yuan drama, mature experience, the continuous development of Ming and Qing into the modern times, through eight hundred years were unbeaten. Now there are more than 360 operas, a variety of singing. Chinese classical opera in its long development has emerged in the process of song and Yuan dynasties, Yuan dynasty, the Ming and qing dynasties, the local opera in the Qing dynasty legend and nearly, modern drama four basic forms.

But as the worlds art treasure of western opera, is an important part of western music culture. Italian opera first appeared in the 16th century, derived from the ancient Greek tragedy of music theatre, then spread to Europe [4]. Heinrich Anschutz, France, and Germany's did, Lully and England's Henry pearl self respectively in their own country, first started in the 17th century opera, until the 18th century, Italian opera is still the mainstream of European opera. According to its characteristics and the circulating, the different, cent is opera, grand opera, opera, music, drama and other types. Pay attention to control of vocal music, opera and to express people's life, thoughts and emotions to infect the audience, arouse the pursuit of beauty, give a person with inspiration and strength.

\subsection{Singing difference between Chinese opera and western opera.}

Opera is a western stage performance art, simple is mainly or entirely in singing and music to express metasomatism and plot of the drama, opera singing art belongs to the bell canto, its characteristic is the pursuit of sound effects pay attention to scientific vocalization methods and strict vocal music training, pay attention to the use of CLS and decoration [5]. The Chinese drama, opera performance different valued singing and singer's music elements such as traditional vocal music skills.

Compared with Chinese opera, though there are a lot of singing, but overall the music system is a simple generation, with total system of "one song is multi-purpose". Chinese opera music system in 
general, the cavity is divided into the main board, curve of couplet and complex system. These three systems are simplified system of "one song is multi-purpose" even as music couplet body by multiple ti orders, all of them looking also all belong to the same spoke system, namely in tone and singing methods have the same or similar characteristics. Such as Beijing Opera is mainly composed of "Xipi", "Erhuang" two big spoke system compositions, and the two spoke system in general belong to the larger "Beijing Opera" system, there are still the same or similar place.

\subsection{The differences of music system.}

Western opera, no unified tone, not in the true sense of the "opera", is basically a play, a play more music. By the composer, according to the script for each an opera, subject matter, theme, characters, style, etc. , to create new music.

As is known to all, Chinese opera music system in general, the cavity is divided into main board, curve of couplet and complex system. "Plate cavity", refers to the system or structure form of opera and rap music, namely all singing all by all sorts of plate type, such as the original plate, adagio, allegro etc, and all of this plate are derived from the same tone. , such as which, echoing cavity at the plate change present different characteristics, with functions of different artistic so-called "song of couplet", also known as "music system", is refers to the system or structure form of opera and rap music, and corresponding plate cavity, namely all singing by several different it connect, where each ti can separate so-called "Mosaic" repeatedly, is refers to the plate cavity with couplet body piece of integrated system, namely, the change of the same tone of various plate have different orders of it [5]. In Chinese opera music, these three systems coexist, each has his strong point.

\section{The influence of western opera to Chinese opera creation}

Look from the music language, "China's national opera" for the most part borrows opera music form, the pursuit of national style music, Hugh song Opera nationalization orientation. First of all, the character in "China's national opera" aria opera music (especially the main character aria) for reference "plate cavity structure principle".

\subsection{Freehand brushwork in traditional Chinese painting and realistic aspects.}

Chinese opera and western opera art pursuit are beauty, all with their own national culture origin and artistic conception. Chinese believe that "every sound has the heart also. Therefore the ancient Chinese opera art is to emphasize "in my view" aesthetic principles [6]. Westerners believe that art should be "not by things," emphasized the importance of "now" the object philosophy. Chinese drama and poetry, word, songs, endowed with the origin, the relationship between "will" lyric of lay particular stress on, western opera originated from the ancient Greek epic drama, lay particular stress on imitation. Chinese opera is "the freehand brushwork in traditional Chinese painting", western opera "realistic" realistic. The art of the two different aesthetic closely related with music creation method.

\subsection{In the aspect of artistic expression.}

On the opera stage, remove "a table of two chairs" and simple props is not redundant device, drama all performed by actors virtual sexual action. Chinese opera performance life, use a kind of "take its meaning and abandon its shape". Chinese opera as a kind of stage art face a stage of narrow and broad in life. Drama is not like play with the principle of "three are" about life by extruding for performance [6]. But by means of virtual, manufacturing flexibility of time and space, and with the help of vivid acting and audience's imagination and understanding, complete the portrayal of a large wide heaven and earth. Drama can, therefore, in the bright light to create the illusion of the night, can yu Ma Hangzhou on an empty stage.

Western opera is flower information not bandits, takes the stage design, theater movement and costumes realistic integrated arts. Form strives in every level to achieve the real aesthetic orientation. 


\subsection{Actor performance differences.}

Western opera on performance exists in Stanislaw, performing system represented by the western "experience" performance style and represented by Brecht drama theory of western "expressionist" performance style [6]. Chinese opera performance is performance, role in first, it requires that the actor creation Angle of know and understand the role, then jump out to, the correct analysis, find and actor consistent understanding and the understanding of the form. Chinese opera performance pays attention to inner experience, rather than the role experience

European opera is a composer to write drama with music, so both opera composer's personal style, and have different plays a unique personality. Chinese opera and European opera, in the aspect of system performance and the artistic creation has a different, but as a drama music have in common, can absorb each other, common development.

\section{Conclusion}

Drama is the pride of the Chinese nation the value of one chapter, with rich Oriental amorous feelings, the human culture and art treasures, is also one of the most brilliant achievements of drama in the world culture. Traditional drama in contemporary China, however, the reality of the situation is not so optimistic. Although made great efforts to save the drama art in our country, after the founding of new China, has experienced the reform of the "model operas" and other drama, but until now the problem is still not well solved, so that the charm of opera art only when traditional music-drama; a costume play to get into full play, and some appear when I was in the modern dramas. Facing the huge loss of audience and opera troupe, difficult to maintain the status quo of some researchers is helpless to drama called "art" the setting sun. Corresponding to this is that western opera in the west, such as sun dongsheng, progresses day by day, and is acknowledged as the "art of sun", many dramas staged thousands of field, still heyday lasted for decades, continue to create the dual miracle of art and commerce. At the same time make western operas have a positive impact on the Chinese opera creation.

\section{References}

[1] Y. H. Lin, the opera introduction, Shanghai music publishing, 2005, vol. 6, pp. 32-40.

[2] X. Y. Zhang, A Chinese opera and western opera comparative study on a preliminary study, the northern music,, vol. 13, pp. 13-17.

[3] W. J. Zhao, Comparative study of Chinese opera and western opera, opera music in the north, 2009, vol. 2, pp. 23-26.

[4] Q. T. Wang, Chinese opera and western opera different between "solid" and "virtual", Chinese opera, 2007, vol. 7, pp. 12-16.

[5] Ch. L. Liu, The difference between Chinese opera and western opera, Drama in Sichuan, 2007, vol. 8, pp. 65-69.

[6] T. H. Tao, Chinese opera and western opera is a preliminary study, Journal of Jilin College of art, 2012, vol. 2, pp. 31-34. 